\title{
Investigating Health Promotion in the Light of Theories of the Policy Process: The Perceptions of Finnish Practitioners
}

\author{
Fulvio Rizzo (PhD) (corresponding author) \\ Department of Geographical and Historical Studies, University of Eastern Finland \\ Yliopistokatu 2, 80100 Joensuu, Finland
}

Tel: 358-442-776-196 E-mail: fulvio.rizzo@uef.fi

Received: December 11, 2017

Accepted: February 2, 2018 Published: March 20, 2018

doi:10.5296/ijssr.v6i1.12279

URL: http://dx.doi.org/10.5296/ijssr.v6i1.12279

\begin{abstract}
As a new form of health governance, health promotion still lacks a distinctive institutional structure. Thus, it is important to engage it more with social science in order to explain goals, perceptions, and events among a variety of stakeholders. This manuscript investigates health promotion approaches, structures, and implementations by a qualitative study undertaken in the region of South Savo, Finland, with practitioners from the public, private and third sectors. The analysis reveals that health promotion appears to be a random result of the conflicting interests, motives and struggles of different people and institutions in different areas of policy making. The effectiveness of health promotion could be improved both by increasing the skills of practitioners involved with such policy field, and by further developing the comprehensiveness and inclusiveness of accessible services. A better integration of the health information of private individuals and specific population groups is also desirable.
\end{abstract}

Keywords: health promotion policy, health governance, top-down, bottom-up, qualitative study

\section{Introduction}

\subsection{The Concept of Health Promotion}

Health promotion is a concept that by its intrinsic nature is contested. Beyond being culturally (Al-Bannay et al., 2013) and values driven (Carter et al., 2011), De Leeuw (2013, p2) has characterized it as inherently political. He goes on to say that "health promotion is 
redefined, compromised, challenged, snowed under, massaged, and somewhat ridiculed". After the first revolution of public health, which dealt with communicable diseases, and a second that focused on chronic diseases, contemporary society is now seen as entering a third revolution where "promoting health must focus on enhancing people's capacities for living" (Breslow, 1999 p1031; Potvin \& McQueen, 2010).

Broadly speaking, health promotion targets a variety of factors which range from risky health behaviours (including poor diet, smoking, and alcohol consumption) to broader social determinants of health (Warr et al., 2012, p96), such as social welfare, maintaining safety and participation, and reducing marginalization (Kuninkaanniemi, 2011). As an umbrella term (Green and Tones, 2010), it applies knowledge that is generated through epidemiological methods. Furthermore, it involves community engagement and partnership building, which are important dimensions of its practice (Warr et al., 2012, p96). Some of the approaches to health promotion are more top-down - mostly within the control of health professionals and the state (e.g. medical and societal approaches) — while others have a more bottom-up character (negotiated) where emphasis is placed on the empowerment of the individuals and/or communities. To a different degree and geographical contingency, these two opposites co-exist within public health (Thompson, 2014).

Since the publication of Healthy People: The Surgeon General's Report on Health Promotion and Disease Prevention (1979), the concept of health promotion has been progressively gaining recognition. However, "health promotion is still lacking the institutional tools that would make it recognized as a science" (Potvin and McQueen 2010, p14). In recent years, discourses on health promotion have gone global (the so called de-territorialization of health (Kickbusch, 2010)), and the Bangkok Charter in particular has reinforced visions and commitments for a global community of health promotion practitioners (Potvin and Jones, 2011). A series of World Health Organization (WHO) conferences started in Ottawa in 1986, with the most recent held in Helsinki in 2013, have increasingly consolidated an approach that puts health on the agenda of policy makers in all sectors and at all levels (the so-called Health in All Policies Approach (HiAP) (Den Broucke, 2013; Leppo et al., 2013)). The principle of inter-sectoral working which is able to link social, economic and human development, is the basis for health promotion efforts (Ziglio et al., 2000).

At national and regional levels there are numerous instances of how health promotion shapes health policies (Potvin and Jones 2011). Thus it is important to investigate its spatial variation, along with its approaches, structures and practices. In Finland for instance - where horizontal and comprehensive health policy has a long history (De Leeuw, 2014; Kokkinen et al., 2017) and where there is a well-established tradition of cooperative and inter-sectoral working - health promotion is a specific function of public health. To various extents, it is regulated and supported by the National Health Law (Kansanterveyslaki) (928/2005), by the Health Care Act (Terveydenhuoltolaki) (1326/2010), by legislation regarding infectious diseases, tobacco and alcohol, and by a variety of national and regional health promotion strategies and programs (Terveyden ja hyvinvoinnin laitos, 2011). 


\subsection{Aim of the Paper}

This paper looks to investigate how health promotion policy phenomena were perceived and defined by practitioners in South Savo, Finland. The core objectives were specifically:

- How is health promotion approached?

- What is the perceived role of the health promotion stakeholders and beneficiaries?

- How is health promotion implemented?

Health promotion is defined here as a combination of "a structured discourse and a set of practices" (Potvin and McQueen, 2010 p16), and also as a "new form of health governance" (Kickbusch, 2010 p144). In such light and in contrast to a linear model of policy-making, this manuscript aims at strengthening the theoretical grounding of health promotion by identifying "processes, issues, events, and actors that have facilitated or compromised the effectiveness of policy" (Breton and de Leeuw, 2010 p84). The main assumption is that individuals both act within collective settings, and, at the same time, they are the agents who create and change policies.

A policy-making process is "rarely characterized by rational decisions made on the basis of the best information" (Young and Quinn, 2002 p218); as well, it is dynamic, and involves a variety of actors and constant changes (Bernier and Clavier, $2011 \mathrm{p} 111$ ). By discussing how health promotion policy participants influence policy processes, the findings can guide health promotion practitioners to critically analyze policy phenomena in order to gain an understanding of what should be changed and improved (Breton and de Leeuw, 2010). The remainder of the manuscript is structured as follows. The next section discusses the theories of the policy processes employed to approach health promotion. This is followed by the data and methodological approach used, presentation of the findings, and discussion. Together these provide new insights for health promotion policy and for future research in this field.

\section{Theoretical Background}

Partially due to difficulties in definition, and also due to the lack of a distinctive institutional structure, in its short history "health promotion has not paid enough attention to theories of social science" (Potvin and McQueen, 2010 p19). Thus, it should engage more with such theories, borrowing their methods, instruments and theoretical understanding of the world (Potvin and McQueen, 2010). In the third revolution of public health, health promotion leads to the creation of new social institutions and organizations, and "it changes the most intimate dimensions of personal and daily life" (Kickbusch, 2010, p146).

Within this context, the theoretical framework of this manuscript is formed by theories of the policy process, which explain goals, perceptions, actions and events among a variety of stakeholders, and lead to specific sets of policy outcomes (Breton \& De Leeuw, 2010; see also Sabatier, 2007). The policy process is defined as "the study of change and development of policy and the related actors, events, and contexts" (Weible et al., 2012, p3). Firstly, the numerous actors involved in one or more aspects of the process range from interest groups to public and private organizations. Secondly, a policy process or cycle requires time (usually a 
decade or more), and it spans from the emergence of a problem to the gaining of sufficient experience for the formulation and implementation of measures, and their subsequent evaluation. Thirdly, within a policy domain such as health promotion, there are many different programmes and strategies involving different levels of government, and governance at local, national and international levels. Fourthly, policy debates imply technical disputes over the severity of a problem, its causes, and the range of impacts of alternative policy solutions. Last but not least, the policy process involves deeply held values and interests, and at some point, a degree of authoritative coercion (Sabatier, 2007).

Because of the complexity of the policy process, the investigator "must find some way of simplifying the situation in order to have any chance of understanding it" (Sabatier, 2007 p4). At the same time, a policy process is so multifaceted that "the assumption that a single framework or theory can explain all its facets and effects is absurd" (Weible et al., 2012, p.2). In this manuscript, the combination of two interlinked approaches is used to address the research questions: a political science approach and a policy network approach. The political science approach focuses on understanding how public policy-making works, and it pays attention "to the policy environment in which decision-makers make decisions and to how this environment offers constraints and opportunities to promote the different actors' interests and their capacity to influence policy outcomes" (Bernier \& Clavier, 2011 p111). Thus, the understanding of a policy includes a variety of issues which influence on policy orientation (such as problem definition, formulation, implementation and resources), and also policy determinants (for instance, the changing constellation of actors, administrative arrangements and pre-existing programs) which contribute to the shaping of public policy (Bernier and Clavier, 2011). A policy environment, on in other words a policy sub-system, brings together policy participants who focus on a particular policy issue within a specific territorial area. For individuals who want to achieve their goals, understanding the structure of the policy system is crucial; at the same time, policy subsystems do not operate in a vacuum. The macro-setting, as the culture of a society, and its administrative settings need also to be taken into account (Weible et al., 2012).

The policy network approach comes from different perspectives on network governance, and is more of an analytical toolbox rather than a theory since "it conceptualizes policy making as a process involving a diversity of actors who are mutually interdependent" (Adam \& Kriesi, 2007, p146). "Modern governance is characterized by decision systems in which territorial and functional differentiation disaggregate effective problem-solving capacity into a collection of sub-systems of actors with specialized tasks and limited competence and resources" (Börzel, 1998, 260). To explain the emergence and form of policy networks in specific policy subsystems, it is necessary to take into consideration general policy-specific variables and situational policy-specific variables, which in one way or another have an impact on the structure and change of policy networks. For instance, policies differ according to the resources they provide for group formation, the expectations they raise among groups, the traceability of their effects, as well as their visibility. "The policy monopoly of a dominant coalition remains intact as long as it is not destabilized by exogenous shocks and/or the mobilitization of competing coalitions". Exogenous shocks may vary from economic and 
technological developments, to ideas, values and knowledge. One can argue that there is no single determinant of policy networks, but rather, a complex combination of factors has to be taken into account to understand the variations in policy networks (Adam \& Kriesi, 2007 p42).

\section{Method and Methodology}

\subsection{Sample}

The core data is drawn from fifteen interviews, structured according to four themes: 'key informant's background', 'health promotion approaches', 'health promotion structures', and 'health promotion implementation' (Table 1). The interviews were undertaken with health promotion practitioners from the public sector $(n=7)$, the third sector (non-profit organizations) $(n=6)$, and from the private sector $(n=2)$. In the public sector, interviews were conducted at the local Regional Council and Health Care Districts of the Mikkeli municipality, and at the Eastern Finland Social Centre of Excellence (known as ISO). For the third sector, interviews were conducted with representatives from the local Memory Association, Hearth Association, Mental Health Association, from the South Savo Sports Federation, from the Lutheran church, and from the Finnish Federation for Social Affairs and Health (known as SOSTE). In the private sector, interviews were collected from two private health care providers (Terveystalo, and Etelä-Savon Työterveys Oy). While some of the interviewees were chosen for their health promotion expertise in the region and beyond, others were selected on the basis of the snowball method.

The idea was to collect different point of views from a variety of sectors on the perceived structures and practices that characterize health promotion in South Savo, and to some extent the broader Finnish context. Similar to Caniëls and Van den Bosch (2011), the goal of the interviews was to gain an understanding about the processes regional health promotion actors have which may enhance their internal motivation, as well as their ability to implement available knowledge. To protect the privacy of respondents, the data extracted from the interviews has been anonymized. The core data was supported by health promotion literature and policy reports.

Regarding the professional background of the interviewees, the main areas of expertise lay in both nursing and civil/health care administration. Other professional backgrounds included work in politics, research, consultancy, social work, medicine and teaching. At least twelve of the interviewees had undertaken a variety of working roles in their career, which indicates that they have acquired experience in health promotion both at the practical and development (through projects) level. All of the interviewees had a direct or indirect familiarity with project work, and in five cases they had started their career in the nursing field, shifting later into the administrative field. 


\section{MInstitute Macrothink $_{\text {Intion }}$}

Table 1. Interview structure

\section{Semi-structured interview}

I. Key informant's background

1) Could you please briefly describe your professional background?

II. Health promotion approaches

2) How would you describe the dominant approach to health promotion in this region?

\section{Health promotion structures}

3) Could you describe the various roles covered by various institutions/actors concerning health promotion?

4) What additional actors may be included, if any?

5) Effective targeting requires access to information including: 1) disease burden; 2) who is at risk; and 3) where interventions are needed. Is such information available in the region, and to what extent is such information integrated?

\section{Health promotion implementation}

6) Innovation is needed in many forms and at all levels for health promotion to progress. Has innovation been successful in this region, and what should be improved?

7) Where investments in health promotion should be targeted as a priority?

8) How can Universities of Applied Sciences contribute to the strengthening of health promotion?

\subsection{Analysis}

Before submitting it for publication, the manuscript has been sent by email to the interviewees for potential feedback. Six of them have replied, suggesting changes at the technical and structural level. The interviews have been analyzed by way of thematic content analysis and narrative analysis. For thematic content analysis, 'descriptive codes' were identified to emphasize the most recurrent perceptions of the interviewees; secondly, 'interpretative coding' was undertaken by grouping together 'descriptive codes' which shared common interpretations; thirdly, the 'overarching themes' of the interviews were abstracted (Fairclough, 2004). Narrative analysis has been used to provide "the bigger picture" of how 
the specific research objectives of the study (previously described) have been addressed by the interviewees. Unless otherwise specified by the use of references, the findings are representative of the results of the interview analyses.

\subsection{Study Area and Health Promotion Policy Context}

The region under investigation is located in south-east Finland. Similar to some Finnish regions (especially those in the east and north of the country), in South Savo the age structure of the population is skewed towards the oldest age groups. The elderly population in these areas is growing faster than in the rest of the country, and what is more, there are a high number of people with health problems (South Savo Regional Council, 2012). Because of these factors, investigating health promotion policy phenomena in South Savo has relevant implications for the fulfilment of broader regional policy and development targets, such as an effective provision of welfare and health care services in urban and rural areas.

In this region, the debate on health promotion is at the forefront within policy-making, and it dates back officially to the year 2008, when a specific working group on the subject was created, and its key strengths and weaknesses were outlined (Kuninkaanniemi, 2011). The South Savo Regional Council has set in its strategy the ambitious target of becoming the model health and welfare promotion region by 2020. Health promotion represents one of the key drivers of success as part of the provision of high-quality welfare services (South Savo Regional Council, 2012; Mikkeli University of Applied Sciences, 2013). The key target are families with children, young people and working age people. Promoting health and welfare means creating opportunities for supporting health choices, as well as identifying risk factors and preventing problems (Frohlich et al., 2017). Such actions should be based on the trust of people and their communities. Most importantly, the promotion of health and welfare is not confined within the responsibility of one single actor; rather, it is organized within municipalities across administrative borders" (Etelä-Savon maakuntaliitto 2014, 37). Also the Strategy of Mikkeli University of Applied Sciences 2017 emphasizes the promotion of health through a variety of actors including the Juvenia Research and Development Centre, and the Elixiiri Unit for Welfare Services. It is specifically emphasized that "the promotion of active ageing, the prevention of social exclusion of young people and the application of technology as part of the reform of welfare services are some of the cornerstones of the development work." (Mikkeli University of Applied Sciences 2013).

\section{Findings}

\subsection{Health Promotion Approaches}

According to the thematic analysis of this study (see Figure 1), the data extracted from the interviews reveals the following interdependent, overarching themes: the contested nature of health promotion, its innovative character, and last but not least its key targets: all ages and all sectors.

It is object of a lively debate among the interviewees how health promotion is approached in the region. While four of them remark that it is a top-down phenomenon, three state that it is bottom-up. According to most of the interviewees, the bottom-up approach will become more 
noticeable in the future, but it needs both support at a national level and adequate knowledge.

"We have very good expert knowledge, and our experts work in quite large networks, but at the same time our experts' skills should be increased in order to implement bottom-up approaches." (interviewee from the public sector).

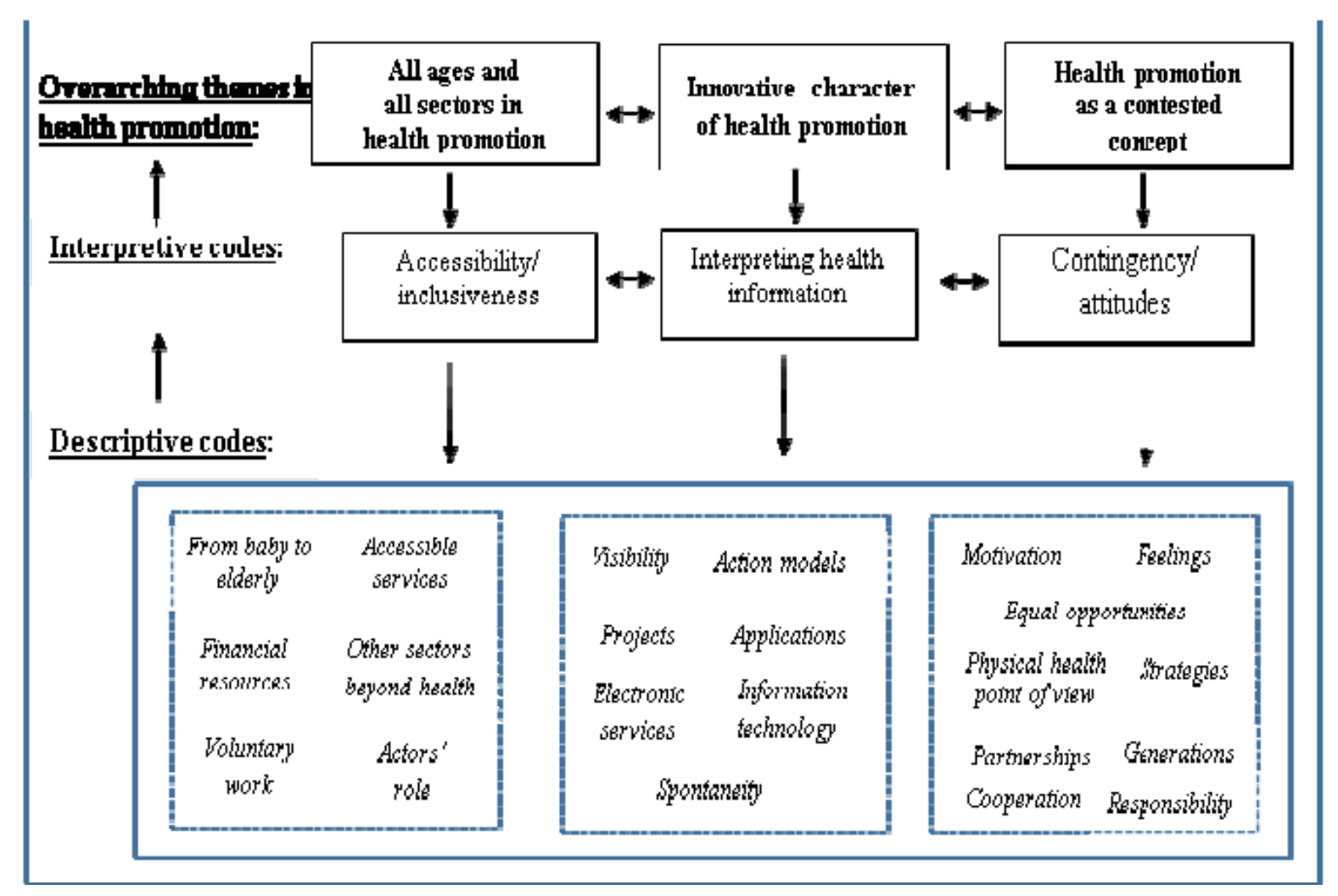

Figure 1. Thematic analysis of the semi-structured interviews

Two of the interviewees remark that a combination of a top-down and a bottom-up approach would be an ideal solution, and important issues are how services should target people, and what kind of services people need. Laverack (2006, p116) states that on the one hand, the initiation and progress of empowerment are often professionally led, but on the other hand, an individual's control has an influence on their health and wellbeing. The latter position is also defined as the reflexivity of health, whereby "every choice in daily life becomes a choice for or against health" (Kickbusch, 2010 p152).

The data shows that this is especially true within occupational health, where the starting point is that individuals have the need, and above all the motivation for improving their health. At the same time, occupational health actors have an obligation to implement initiatives to actualize such motivations. To a varying degree, other interviewees define health promotion in terms of other factors, including geographical contingency, generational attitudes, as well as health promotion values and intrinsic characteristics. Geographical contingency indicates that health promotion varies from place to place, and depends upon the actors involved. When speaking about generations, whilst older generations are often influenced by authority, 
younger generations are more inclined to run their life by themselves. So, this variation in control may have profound implications on the way how health promotion is approached. Two interviewees stressed that, although the situation is starting to change, the dominant approach to health promotion still stems from a physical health perspective.

Because of this, sectors/actors other than health and social care should be included within health promotion, including for instance housing, education, the environmental sector, food companies, as well as religious volunteer institutions. This concept is in line with Kickbusch (2010 p158), who claims that "in health society, health has become a "co-produced" good which needs the cooperation of many sectors and actors in society", and it is also confirmed by the HiAP shaped by the World Health Organization. As for other potential actors, health promotion should be approached in terms of the concept "from the baby to the elderly", so that all age groups are involved. Last but not least, health promotion is perceived as intrinsically innovative and project-based. This means that while health information is available and plentiful, practice, implementation, and change requires both innovative thinking and actions. Also, as health promotion is mostly implemented through projects, this leaves big questions as to what happens after a specific project is concluded, and how innovative initiatives should be made as permanent as possible and effectively spread.

Despite the importance of health promotion within policy-making and policy debates, the empirical material shows that doubts are cast on the strength of its strategies at both national and regional levels. This concerns not only the weak level of finances which are allocated to it, but also its concrete implementation. For instance, it has been remarked that at the national level, the role of health promotion has weakened in comparison to previous times when there was a specific centre (referring to the Finnish Centre for Health Promotion (FCHP) which was active from 1962 to 2011, and whose key role was to coordinate, network, and develop the quality of health promotion). Furthermore, the health care system is built on correcting problems that arise and treating diseases, but not much is done in regard to disease prevention. The following two quotations best summarize these doubts:

"In the official programs and legislation the importance of this work [health promotion] is emphasized, but in practice quite little has been done." (public sector interviewee).

"In debate, health promotion is very strong, but financially speaking it is quite weak." (third sector interviewee).

In a study by Ziglio et al. (2000), it is stated that European member states have been undertaking health care reforms whose goal is simply to reduce costs, rather than looking at the broader picture which would optimize the health promoting impact of a wide variety of policies. Thus, it is suggested that important actions would include the creation of national/regional centres for health promotion, the strengthening and sustaining of local expertise by appropriate organizational arrangements, and by increasing capacity with relevant research. 


\subsection{Health Promotion Structures}

Sabatier (2007, p3) states that the policy process involves a variety of actors; each of whom "has potentially different values/interests, perceptions of the situation, and policy preferences". From the interview material, it emerges that in South Savo the operating system for running health promotion in the area is not yet clear in regard to either the tasks to be performed, or the roles of the various stakeholders involved. Since it is a new form of health governance, this circumstance is in a way "typical" of health promotion as a whole, and as an embryonic, challenged and challenging policy, health promotion is in a constant process of redefinition. Municipalities appear to have key roles, but at the same time, they do not have much bargaining power in relation to health care districts. Especially, in the current economic situation most of the funds are devoted to health care rather than to health promotion. Thus, a good compromise would be to find the right balance between the welfare work of municipalities, and the larger organizations who are responsible for health (e.g. health care districts). What is more, as remarked by two interviewees from the third and public sectors, although municipalities produce welfare reports, there are neither strong health promotive indicators, nor concrete bottom-up ideas. At the same time, the Regional Council is not directly active, but supports actions leading towards health promotion, while the Regional State Administrative Agency is seen as a supervisory agent.

Similar to municipalities, third sector organizations are also perceived by interviewees as having a relevant role in health promotion. It is seen as important that the authorities and third sector organizations do not undertake the same work, and also have a clearly agreed understanding of the division of labour. The public authorities should look to support more third sector organizations, who in turn see their work as more educational, informational and preventive than public care work. At the same time, it cannot be forgotten that in the public sector relevant promotional and preventative work is provided by prenatal care activities, school health care, and adult health clinics. As for the private sector, it is seen to have a key role for working people who are linked to some kind of private health organization. An interviewee from the private sector remarked that:

"Looking at the future, the most important thing is that 'barriers' will fall, and we, private, along with the public and third sectors undertake health promotion together."

Another important issue that emerges from the interviews deals with how health promotion addresses its potential beneficiaries. In South Savo, health promotion has mostly targeted working age people, and also young people to a moderate degree. As for older people, attention is paid to those who are already in some form of health care institution. However, it is an often neglected fact that the majority of people who are older than 75 still live at home, and in their case there is little preventive action being undertaken. Since most of these older people are still in relatively good condition, they also need some measures to be taken so that they remain in good physical condition. It is also a subject of debate as to whether health promotion projects concerning the elderly are effectively able to target this population group.

The policy orientation of health promotion is not only influenced by stakeholders' arrangements and by effectively targeting beneficiaries, but also (and very importantly) by 
processing health information. Effective targeting requires access to information including details of the disease burden, who is at risk, and where interventions are needed (Kenyon, 2014). The data suggests that although health information is the key platform upon which health promotion actions can be developed, its management is fragmented, and at best, unrefined. On the one hand it is acknowledged that there are good statistics and welfare indicators (especially at the national level), yet on the other hand, it is also acknowledged that the patient information system is patchy. For instance, children's maternity clinic information remains in the clinic, school health information remains in schools, and so on. This is due to the fact that in Finland, the protection of private individuals' information is established by law. Thus, this data fragmentation prevents cooperation between the authorities involved, and also limits the possibility of forecasting potential diseases.

\subsection{Health Promotion Implementation}

In spite of the fact that they are not easy to evaluate and have a high failure rate, inter-sectoral partnerships are recognized in literature as being an integral part of health promotion practice (Jones and Barry, 2011). In South Savo, the welfare sector partnership appears to be a relevant network organization that enables health promotion implementation. The partnership is represented by municipal social welfare and health care, welfare sector companies and organizations, research and educational institutions, the Ministry of Labour, as well as corporate and business services. Such a partnership comprises of expert knowledge and networks, and is run by the Regional Council. Its main task is to support the renewal of services, as well as the development of livelihood policy (Kumppanuuspöytä, 2012). It is very important for this network partnership to ensure that there are no overlapping actions between the various actors, and to strengthen the cooperation between the two health care districts of the region. Another key civil servant organization which has implications on health promotion in the region is the Eastern Finland Social Centre of Excellence (ISO), which is one of nine centres in Finland. ISO' $\mathrm{s}$ mission is to strengthen and activate the knowledge, and to promote expert knowledge-based social development. The major partners in this group are for instance municipalities and joint municipal boards, research and training organizations, regional councils, and ministries (ISO, 2001).

At the same time, there are a variety of health promotion practices that have been deemed as innovative, and to some extent as bottom-up initiatives by the interviewees. One example is the role played by the South Savo Sport Federation, which through a variety of projects and a wide range of events, has promoted the quantity and quality of exercise among young and adult people. Also, the TERVIS project (also known as Healthier Eastern Finland) has been indicated as an important step towards bottom-up approaches, where new ways of working have been sought. The TERVIS project aims at increasing the regional planning, know-how and new ways of promoting health, and also preventing illnesses. In so doing, it supports the municipalities in the development and activation of its citizens. Last but not least, it aims at strengthening the cooperation between the public and third sectors to develop action models, such as the Health and Well-being Co-operation (Terveyttä ja hyvinvointia yhteistyöllä, 2013). Other innovative practices which were mentioned were easily accessible services such as the "Understand me!" model, which has the goal of preventing the marginalization of the 
young. The model was first adopted in the Netherlands in 2010, and a modified version adapted to Finnish culture was launched by Sitra and its first trial was introduced in partnership with the city of Mikkeli in 2013 (Sitra 2014). Another example is to link health and culture by way of the arts and theatre, and older people have especially been involved in this initiative. At a national level, a cited innovative and bottom-up practice was SIUN SOTE. Based in North Karelia, citizens have been taking part in the creation and planning of future health services.

It is debated whether electronic services (which have been so far more to do with health care system development rather than health promotion) can be considered as innovative practices. For some interviewees, the importance of interface electronic services is growing all the time (Lintonen et al., 2008), especially when seen as increasing the availability of services. For others, they are not capable of targeting the people who are most in need of those services, and it is felt that they should not replace the human dimension of health. When asked where financial resources should be targeted to strengthen health promotion, the interviewees concentrated their attention on the overarching themes of easily accessible services and the welfare of all age groups (Figure 2). The latter theme confirms the findings of the thematic analysis depicted in Figure 1, whereas the comprehensiveness of health promotion (through ensuring accessibility for all ages and all sectors) is also emphasized.

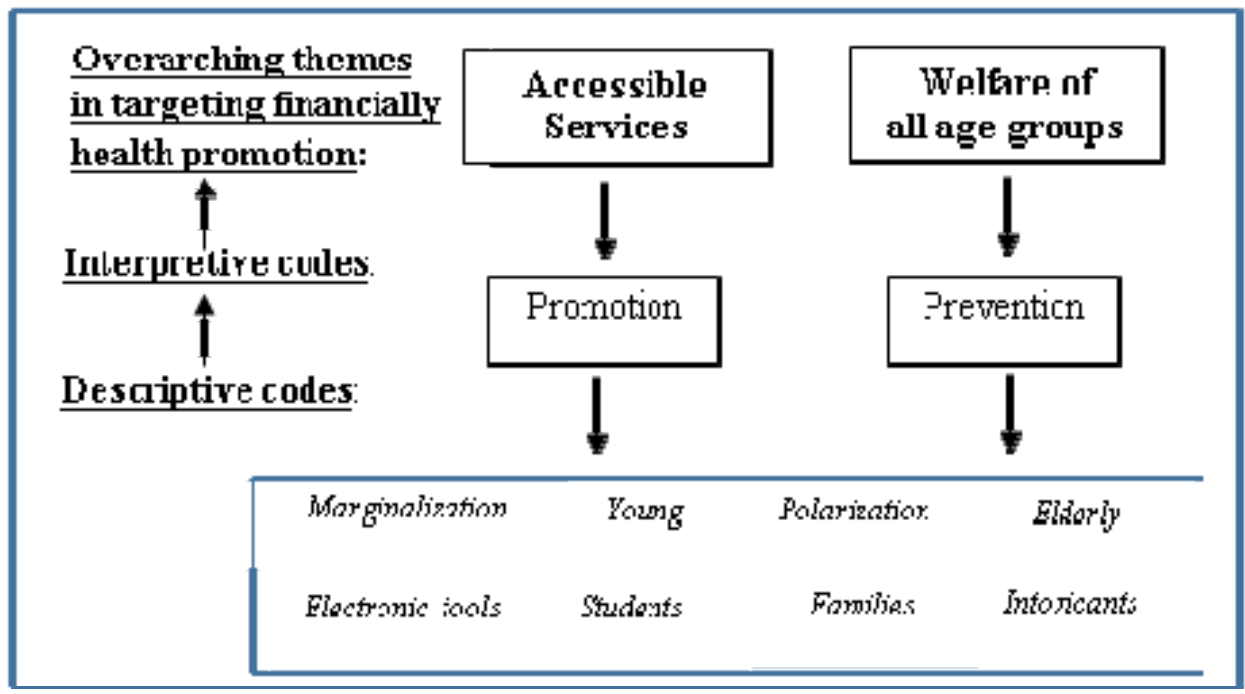

Figure 2. Health promotion and financial resources' targets

All interviewees agreed that the role of higher education is potentially relevant in strengthening health promotion policy and implementation in the region. This has also been suggested by Molleman and Fransen (2012), according to whom the exchange of knowledge between practitioners, policy-makers, researchers and higher education is very important, and has become one of the most concrete applications in the Netherlands with the creation of Academic Collaborative Centres (ACC). Individualistic approaches to health promotion should acknowledge the importance of wider social structures (Robertson \& Baker, 2017). The interview data reveals that one key task which may be undertaken by higher education 
institutions on a regular basis is the evaluation of health promotion projects' results, their efficacy and best practices. In turn, this may help with the coordination of projects within the region and avoid any overlap between regional actors (see for instance the recent work by Moilanen and Mäkeläinen, 2014). In a study by Brandstetter et al. (2012), evidence shows that the idea of evaluating empowerment and participation is supported by health promotion practitioners; but at the same time, the resistance of health authorities to empowerment initiatives was seen as a challenge for funding evaluations. Another key task run by higher education could be undertaking population research, whose goal would be to improve the inclusiveness of health promotion tools. This is for example very important when investigating the effectiveness of so called easily accessible services.

\section{Discussion}

In the light of theories of the policy process (particularly by taking a political science approach and a policy network approach), this manuscript has shed light on how health promotion practitioners perceive a variety of policy phenomena, including actors, approaches and implementation practices in the context of South Savo, Finland. More specifically, it has served to strengthen the theoretical grounding of health promotion by identifying processes, issues, events and actors that may facilitate, or rather, compromise the effectiveness of health promotion policy. Similarly to Weible et al. (2012, p4) "cognitive characteristics of individuals in combination with individuals' contextual environment are key factors shaping policy processes". As the results suggest, in order to overcome territorial and functional differentiation of health promotion policy, which occur when individuals protect their interest against an adversarial coalition, the following strategies may be undertaken. Firstly, the development of new knowledge, by acquiring and learning for instance multi-analytic or interdisciplinary competencies (both within the own subsystem or within other subsystems); secondly, the investment in networks by resource exchange and acquisition, and, thirdly, participation for a long period of time. In the latter case, tension and conflict can last for long periods before negotiation and cooperation take place.

Although the results of this qualitative study may be perceived as exclusively contingent to the Finnish setting (especially where in the wider context, similar issues can be found), they may also be replicable in contexts which are culturally, socially and administratively similar. Although such a study does not represent a comprehensive overview of health promotion in South Savo, it is an important step in gaining an understanding about how a variety of health promotion policy phenomena are perceived by key experts in the field. To integrate and develop the results of this study, future research could explore for instance how the media perceive health promotion at national and local levels, and also an evaluation of the inclusiveness and empowerment of health promotion initiatives. As confirmed by the literature and by the findings, policy-making is not necessarily the result of rational decision-making; rather, it is the contested intertwining of a variety of different policy orientations and policy determinants. In this regard, Weible et al. (2012, p3) argue that "success or failure in the policy process is a matter of odds... which are grounded in diverse and well-established public policy theories and frameworks". 
As a new form of health governance, on one hand health promotion involves formal and informal arrangements between a variety of social institutions/actors whose cooperation needs to be strengthened (possibly by educational institutions). On the other hand, it emphasizes how health promotion is about attitudes and feelings towards life, and the perspective that individuals do have an influence on their own health and wellbeing. As a combination of structured discourses and a set of practices, evidence has shown that health promotion represents an important bridge between social sciences and public health. Furthermore, the thematic analysis of the study data has confirmed that health promotion represents a third generation of interpreting peoples' health, and is intrinsically anchored in its innovative, comprehensive and contested character.

\section{Conclusions}

In the region of South Savo, Finland, the relevance of the debate on health promotion offers an answer to some of its structural problems, especially those of aging and illness. The concept of health promotion is approached by practitioners in terms of its levels of application, macro-system contingencies, generational attitudes, and in terms of the values and characteristics which are intrinsically attached to it. The collected data reveals that health promotion appears to be the random result of the conflicting interests, motives and struggles of different people and institutions in different areas of policy making. Its vision needs to be as broad as possible, not only by including actors that may currently be excluded, but also by defining its definition and strategies. A better integration and interpretation of health information is a key aspect to consider, when looking to improve the innovativeness of health promotion. What is more, it is important to find the right balance between top-down and bottom-up approaches, both by increasing the skills of health promotion personnel, and by further developing technology-based tools which will support the 'human' dimension of interpreting health. Especially, easily accessible services and the welfare of all age groups must be key targets. While civil servant partnerships have a high relevance in devising and implementing health promotion initiatives, it is undeniable that in South Savo there have been many successful examples of innovative/bottom-up practices which are increasing not only in number, but also in developing the level of stakeholders' awareness.

\section{References}

Adam, S., \& Kriesi, H. (2007). The network approach. In P.A. Sabatier, (Ed.), Theories of Policy Process. New York, Westview Press.

Al-Bannay, H., Jarus, T., Jongbloed, L., Yazigi, M. \& Dean, E. (2013). Culture as a variable in health research: perspectives and caveats. Health Promotion International, 29, 549-557.

Bernier, N. F. \& Clavier, C. (2011). Public health policy research: making the case for a political science approach. Health Promotion International, 26, 109-116.

Brandstetter, S., Mccool, M., Wise, M. \& Loss, J. (2012). Australian health promotion practitioners' perceptions on evaluation of empowerment and participation. Health Promotion International, 29, 70-80. 
Breslow, L. (1999). From disease prevention to health promotion. JAMA, 281, 1030-1033.

Breton, E., \& de Leeuw, E. (2010). Theories of the policy process in health promotion research: a review. Health Promotion International, 26, 82-90.

Börzel, T., (1998). Organizing Babylon - on the different conceptions of policy networks. Public Administration, 76, 253-273.

Caniëls, M. C. J., \& Van den Bosch, H. (2011). The role of Higher Education Institutions in building regional innovation systems. Papers in Regional Science, 90, 271-286.

Carter, S. M., Rychetnik, L., Lloyd, B., Kerridge, I. H., Baur, L., Bauman, A., Hooker, C. \& Zask, A. (2011). Evidence, ethics, and values: a framework for health promotion. American Journal of Public Health, 101, 465-472.

De Leeuw, E. (2014). The eight global conference on health promotion: health in all policies: from rhetoric to action. Health Promotion International, 29, i1-i8.

De Leeuw, E. (2013). Health promotion research: war on health, battle of bulge or conflict of confidence? Health Promotion International, 28, $1-3$.

Etelä-Savon maakuntaliitto (2014). Maakunta ohjelma vuosille 2014-2017. Julkaisusarjan nro: 126/2014.

http://www.esavo.fi/resources/public/Maakuntaliitto/Maakuntaohjelma/Maakuntaohjelma_20 14-2017.pdf

Fairclough, N. (2004). Analysing discourse: textual analysis for social research. Taylor \& Francis, London.

Frohlich, K.L., Poland, B., \& M. Shareck (2017). Contrasting entry points for intervention in health promotion practice: situating and working with context. In Rootman, I., Pederson, A., Frohlich, K.L., \& Dupéré, S. (Eds.). Health Promotion in Canada. New perspectives on theory, practice, policy, and research. Canadian Scholars' Press, Toronto.

Green, J. \& Tones, K. (2010). Health promotion. Planning and strategies. SAGE Publications Ltd, USA.

ISO. Tietoa, taitoa, toiminta (2001). http://www.isonet.fi/organisaatio

Jones, J. \& Barry, M. (2011). Exploring the relationship between synergy and partnership functioning factors in health promotion partnerships. Health Promotion International, 26, 408-420.

Kenyon, T. (2014). Advancing global health through investment, information, and innovation. Harvard International Review, 35. http://hir.harvard.edu/archives/5807

Kickbusch, I. (2010). Health governance: the health society. In McQueen D. V., Kickbusch, I., Potvin, L., Pelikan, J. M., Balbo, L. and Abel, T. (Eds.), Health Modernity. The role of theory in health promotion. Springer Science, USA.

Kokkinen, L., Muntaner, C., O’ Campo, P., Freiler, A., Oneka, G., \& K. Shankardass (2017). 
Implementation of Health 2015 public health program in Finland: a welfare state in transition. Health Promotion International, 1-11.

Kumppanuuspöytä. Hyvinvointialan kehittämisrakenne Etelä-Savossa (2012). https://kumppanuuspoyta.wordpress.com/

Kuninkaanniemi, H. (2011). Maakunnallinen hyvinvoinnin ja terveyden edistäminen ohjelma 2011-2014. Savilahden Kirjapaino, Mikkeli. Retrieved from http://www.esavo.fi/resources/public/media/Hyvinvointiohjelma.pdf

Laverack, G. (2006). Improving health outcomes through community empowerment: a review of the literature. Journal of health, population and nutrition, 24, 113-120.

Leppo, K., Ollila, E., Penã, S., Wismar, M. and Cook, S. (2013). Health in all policies. Seizing opportunities, implementing policies. Ministry of Social Affairs and Health, Finland, 2013.

Retrieved

from

http://www.euro.who.int/_data/assets/pdf_file/0007/188809/Health-in-All-Policies-final.pdf ?ua $=1$

Lintonen, T. P., Konu, A. I., and Seedhouse, D. (2008). Information technology in health promotion. Health education research, 23, 560-566.

Melkas, T. (2013). Health in all policies as a priority in Finnish health policy: a case study on national health policy development. Scandinavian Journal of Public Health, 41, 3-28.

Mikkeli University of Applied Sciences (2013). Mikkelin ammattikorkeakoulu strategia. Mikkeli.

Retrieved

from

https://www.mamk.fi/instancedata/prime_product julkaisu/mamk/embeds/mamkwwwstructu re/20831_Mamk_2017_strategia_low.pdf

Moilanen, H. and Mäkeläinen, P., (2014). "Kokonaisuudesta irrallaan oleva hanke ei jää elämään” Hyvinvointihankkeiden vaikutusten arviointi Etelä-Savossa - hankkeen loppuraportti. Retrieved from file://C:/Users/hfuri01/Downloads/D68_978952493226-4\%20(2).pdf

Molleman, G. and Fransen, G. (2012). Academic collaborative centres for health promotion in the Netherlands: building bridges between research, policy, and practice. Family Practice, 29, 157-162.

Nutbeam, D., Harris, E., Wise, M. (2010). Theory in a nutshell. A practical guide to the health promotion theories. McGraw-Hill, Australia.

Potvin, L. \& Jones, C. M. (2011). Twenty-five years after the Ottawa Charter: the critical role of health promotion for public health. Canadian Journal of Public Health, 102, 244-248.

Potvin, L. \& McQueen, D. V. (2010). Modernity, Public Health, and Health Promotion. A reflexive discourse. In McQueen D.V., Kickbusch, I., Potvin, L., Pelikan, J. M., Balbo, L. \& Abel, T. (eds), Health Modernity. The role of theory in health promotion. Springer Science, USA. 
Robertson, S., \& P. Baker (2017). Men and health promotion in the United Kingdom: 20 years further forward? Health Education Journal, 76 (1), 102-113.

Sabatier, P.A. (2007). Theories of Policy Process. New York, Westview Press.

Sitra (2014). Tajua mut! -toimintamalli lasten ja nuorten tukena (Understand me! -Action model to support the children and the young). Retrieved from http://www.sitra.fi/julkaisut/Selvityksi\%C3\%A4- sarja/Selvityksia83.pdf

South Savo Regional Council (2012). Uusiutuva Etelä-Savo 2020. Maakuntastrategia. Mikkeli. Retrieved from http://www.esavo.fi/resources/public//Maakuntaliitto/Maakuntasuunnitelma/Maakuntastrategi a_netti.pdf

Terveyden ja hyvinvoinnin laitos (2011). Väestön hyvinvoinnin ja terveyden edistäminen kunnassa. Perusraportti kuntajohdon tiedonkeruusta 2011. Juvenes Print, Tampere.

Terveyttä ja hyvinvointia yhteistyöllä. (2013). Retrieved from https://tervishanke.wordpress.com/tervis $1 /$ sisalto/

Thompson, S. R. (2014). Approaches and models used to promote health. In Thompson, S. R. (ed), The essential guide to public health and health promotion. Routledge, New York.

Young, E. \& Quinn, L. (2002). Writing Effective Public Policy Papers. Open Society Institute, Budapest.

Van den Broucke, S. (2013). Implementing health in all policies post Helsinki 2013: why, what, who and how. Health Promotion International, 28, 281-284.

Van den Broucke, S. (2012). Theory-informed health promotion: seeing the bigger picture by looking at the details. Health Promotion international, 27, 143-147.

Warr, J. D., Mann, R. \& Kelaher, M. (2012). 'A lot of the things we do... people wouldn't recognize as health promotion': addressing health inequalities in settings of neighbourhood disadvantage. Critical Public Health, 23, 95-109.

Weible, C.M., Heikkila, T., deLeon, P., \& P. A. Sabatier (2012). Understanding and influencing the policy process. Policy Science, 45(1), 1-21.

Ziglio, E., Hagard, S. \& Griffiths, J. (2000). Health promotion development in Europe: achievements and challenges. Health Promotion International, 15, 143-154.

\section{Copyright Disclaimer}

Copyright for this article is retained by the author(s), with first publication rights granted to the journal.

This is an open-access article distributed under the terms and conditions of the Creative Commons Attribution license (http://creativecommons.org/licenses/by/3.0/). 